\title{
JAN DE VOS: UNA SELVA DE LETRAS PARA CONJURAR OLVIDOS
}

\author{
De vez en cuando camino al revés; \\ es mi modo de recordar. \\ Si caminara sólo hacia delante, \\ te podría contar cómo es el olvido. \\ Humberto Akabal
}

El 24 de julio de 2011, hace poco más de tres años, la palabra escrita de Jan de Vos pasó a convertirse en el principal medio para conjurar su ausencia. Recurro pues a la escritura esta tarde para hacerlo de nuevo presente, por el simple placer de traer, aunque sea momentáneamente, a un amigo de vuelta, recordando su obra.

\section{铅}

Con 37 años a cuestas y acarreando en su maleta su bagaje de dos años de la carrera de Derecho en Bruselas, estudios en Teología Católica y Protestante en las universidades de Lovaina y Tübingen, y de doctorado en Historia por la primera, Jan llegó a México en 1973.

Nacido en Amberes en el equinoccio de 1936, un 17 de marzo, era sin duda un digno ciudadano de su país: amaba la música como Jacques Brel, el buen decir y el mejor escribir, como Marguerite Yourcenar, la pasión por re-crear imágenes como los pintores flamencos, y el buen comer y beber, como todo belga que se respete. A ello aunaba, como alguna vez le dije, todo para ser un perfecto jesuita: culto, inteligente y vanidoso. Un defectillo que las mujeres encontraban harto justificado teniendo en cuenta su buena estampa, y que los amigos disimulábamos 
a cambio del privilegio de su plática, siempre erudita, siempre cordial, siempre amena.

A los diez años de estar en México, trocó el púlpito y el confesionario que ocupaban su ministerio en el poblado tzeltal de Bachajón por la investigación y la pluma y, por fortuna para nosotros, puso sus cualidades al servicio de la historia de Chiapas.

Humanista revolucionario en el mejor de los sentidos, y recordando acaso aquella sentencia bíblica acerca de lo inútil que resulta edificar sobre arena, buscó fincar sus propios sueños en tierra historiográfica firme, desbrozando mitos y leyendas. Así, para espanto de no pocos chiapanecos, desbarató el mito de un pretendido suicidio colectivo de los otomangues de Chiapa en el cañón del llamado Río Grande en su libro La batalla del Sumidero; descarnó el papel de sectores autoritarios y corruptos de la Iglesia colonial en Fray Pedro Lorenzo de la Nada, arremetió contra dogmatismos indios y mestizos en "Leyendo una leyenda maya: Juan López, rey de los indios" y "Leyendo una leyenda coleta: la maldición de fray Bartolomé", y develó incluso las entretelas de la tan cacareada opción de Chiapas por la mexicanidad en "El sentimiento chiapaneco. Cuarteto para piano y cuerdas. Opus 18211824", que más tarde transformaría en El sentimiento chiapaneco. Ensayo sobre la independencia de Chiapas y su agregación a México (1991).

En esa misma tónica de la re-escritura de una historia chiapaneca más plural e inclusiva, que tomase en cuenta tanto las versiones de los dominadores como las de los dominados, se inscriben textos como Los enredos de Remesal. Ensayo sobre la conquista de Chiapas (1992), su espléndido Vivir en frontera. La experiencia de los indios de Chiapas (1994), que forma parte de la serie Historia de los pueblos indígenas de México, y "Chiapas: tierra de indios, tierra de frailes" (1996), así como sus antologías acerca de las diversas estrategias indígenas para enfrentar distintas formas de dominio, con especial hincapié en aquellas que se tradujeron en resistencias armadas. Muestra de ello son textos como el de La batalla del Sumidero, al que ya me referí, No queremos ser cristianos. Historia de la resistencia de los lacandones, publicado en 1990 y La guerra de las dos vírgenes. La rebelión de Los Zendales, documentada, recordada, recreada, obra que conjunta, 
de manera por demás original, documentos de archivo, fuentes bibliográficas, recreaciones de rituales aún en boga en la antigua Ciudad Real, la tradición oral que se mantiene principalmente entre los tzeltales de Bachajón y Cancuc, y obras de ficción de autores locales, nacionales y extranjeros, permitiéndonos asistir de cerca al ejercicio historiográfico. Este valioso texto, cuya publicación me ofreció para la serie Documentalia del CEPHCIS de la UNAM pocos meses antes de morir, fue finalmente coeditado con el CIESAS y vio la luz en octubre de 2011. Nunca imaginamos, ni él ni yo, que sería publicado como obra póstuma. ${ }^{1}$

Sí alcanzó a ver, en cambio, Camino del Mayab. Cinco incursiones en el pasado de Chiapas, editado por el mismo CIESAS seis meses antes de su muerte, y en el cual se conjuntaron textos inéditos con re-ediciones de otros, alguno en versión más amplia. Allí, junto a una segunda versión de "Leyendo una leyenda maya" u otra sobre "El tesoro de Teopisca", figuran ensayos acerca de la forma en que la provincia de Chiapa terminó formando parte del Reino de Guatemala durante la Colonia — aunque no se detiene allí-, la tensa situación que enfrentaba en la primera década del siglo XXI la "Misión de Bachajón", sede de novedosos intentos por "inculturar" el evangelio acorde a los postulados de la Teología de la liberación, y la no menos tensa que caracterizaba por entonces la cotidianidad de la Selva Lacandona.

Los textos, acuciosos y eruditos como todo lo suyo, se vieron precedidos por una introducción, "La memoria interrogada", que constituye una valiosa reflexión acerca de su quehacer histórico, las técnicas, métodos y la metodología que empleó para satisfacer su deseo de estudiar y comprender el devenir chiapaneco; metodología que presenta a manera de un decálogo que permita al historiador atender a lo que considera cuatro condiciones básicas en un estudio: posibilidad, originalidad, actualidad y utilidad. No hay desperdicio en su lectura, que incluye, a la manera del diario de Bronislaw Malinowski, ciertas confesiones de ignorancia y de fracaso, y gracias a la cual podemos asomarnos al proceso de creación de algunas de sus obras.

\footnotetext{
${ }^{1}$ E igualmente póstumas serán las notas autobiográficas que dejó entre sus papeles, tituladas He vuelto a leer, que he escuchado considera publicar el CIESAS.
} 
Mero ejemplo de esto último es la solicitud que, narra, recibió de los campesinos de Nicolás Ruiz para que les apoyase en documentar su historial agrario, asunto que trata en "El tesoro de Teopisca". En él da cuenta de cómo, tal y como lo habían hecho sus abuelos desde la época colonial, los descendientes del puñado de tzeltales que abandonaron Teopisca en 1868 defendieron exitosamente sus tierras contra la voracidad de las fincas mestizas aledańas, mientras que en épocas recientes no dudaron, dependiendo de la coyuntura, en cambiar de partido político, declararse municipio autónomo, enfrentar a las autoridades o responder a la represión — con saldo de muertos, heridos y encarcelados_, u ostentarse como "pueblo indígena" en 2001, cuando nadie hablaba ya el tzeltal ni era moneda corriente la "conciencia de identidad", con tal de, al amparo del convenio 169 de la OIT, presentarse ante el Tribunal Internacional para acusar al Gobierno "de haberle violentado en sus derechos a la tenencia de la tierra", aun cuando la pesquisa histórica demostró más bien lo contrario.

Por su originalidad y tratamiento destaca en el conjunto el ensayo "Vino nuevo en cueros viejos, o cómo los tzeltales sońaron, por segunda vez, con tener sus propios sacerdotes", que tiende sin disimulo sus raíces hasta el periodo en que Jan se desempeñó como eclesiástico en Chiapas, y en el que da cuenta de los avances y escollos que sufrió la deseada "inculturación del evangelio" en el área de Bachajón, las diferencias entre jesuitas y dominicos en torno a cuestiones como el diaconado permanente, o la renuencia de los representantes de ambas órdenes para apoyar la existencia de estructuras clericales indias - aun cuando fuesen temporales, conforme al tradicional sistema de cargos - chocantes en un modelo de cristianismo que imaginaban estrictamente igualitario, a más del rechazo frontal de la jerarquía católica a la pretensión de conferir el orden sacerdotal a hombres casados. Resumen, en fin, de los avatares de una deseada Iglesia autóctona tzeltal y la posibilidad de rastrear sus antecedentes en la Iglesia alternativa que imaginaron otros tzeltales durante la famosa revuelta de 1712, como lo planteó en este sesudo y por momentos aguerrido texto al que dio formato de carta dirigida a uno de sus antiguos maestros en la Universidad de Tübingen, Joseph Ratzinger, mejor conoci- 
do al momento del escrito como Benedicto XVI, supremo pontífice de la Iglesia católica.

No fue el único escrito que dedicó al tema; vinculados con él están otros previos como "El encuentro de los mayas con la teología de la liberación” (1997), "El arte de las artes: la evangelización vista por los misioneros del siglo XVI" (1998), "De la costumbre colonial a los credos modernos: el proceso de mutación religiosa entre los mayas de Chiapas y Guatemala" (2000) y "La Iglesia Católica en Chiapas" (2000). Todos ellos se nutrieron de su tiempo como estudioso de la teología y de su experiencia como agente de pastoral en la diócesis de San Cristóbal. De su sentimiento de pertenecer a un grupo étnico durante siglos subyugado — “como los indios”, según expresó alguna vez-, surgió en cambio su ensayo "Los flamencos y el Estado belga: crónica de una cohabitación difícil” (1998).

Preocupado por ofrecer versiones regionales de la cuestión fronteriza dedicó diversos escritos a la conformación de los límites entre Guatemala, Belice y México —en particular Las fronteras de la frontera sur, 1993, que ofrece una versión pro-mexicana de los hechos-, y los métodos que consideraba más apropiados para la recreación histórica de tan dilatado y complejo fenómeno, en particular a lo largo del siglo XIX. No dejó tampoco de lado esa otra porción de "frontera" que constituye el Caribe (1988).

No obstante, su pasión chiapaneca más acendrada la plasmó en sus escritos sobre la Selva Lacandona, paisaje que llegó a calificar como "herido de muerte", pero que recreó desde que rebosaba de vida vegetal y animal, atreviéndose incluso a imaginar los sueños de quienes lo contemplaron antes que él. Como si en su rememoración, por momentos intimista, lo hubiesen guiado aquellos versos de Jorge Teillier en su Crónica del forastero: "El bosque se estremece soñando con los grandes animales que lo recorrían. El bosque cierra sus párpados y me encierra”.

La Lacandona adquiere así en sus textos el papel de protagonista en una obra de intenso dramatismo, y en la recreación de cuya ya larga agonía parecerían poder rastrearse formas plásticas surgidas de su tierra y su cultura natal. 
En efecto, como es bien sabido, uno de los legados más importantes de los Países Bajos al arte universal lo constituye la tradición pictórica vinculada a los trípticos, a través de los cuales, como en un fotomontaje cromático, es factible acercarnos a la visión diacrónica de un suceso mitológico, histórico o a veces profético. ${ }^{2}$

Varias de tales obras de arte de la Baja Edad Media y el Renacimiento sobrevivieron a las tendencias pictóricas subsecuentes, aunque fueron muchas menos las que lograron trascender los límites del Siglo de la Luces. Entre los escasos trípticos flamencos que han llegado hasta nosotros destaca el justamente célebre Jardín de las Delicias, debido al genio creador de Hieronimus Bosch, El Bosco, quien muriera en 1516; tres años antes de que Hernán Cortés se recrease ante otra visión deslumbrante y en más de un sentido apocalíptica: Tenochtitlan refulgiendo en un lago.

La obra del holandés Hieronimus Bosch, al parecer originalmente solicitada por Hendrik III de la casa de Nassau, para su palacio en Bruselas, fue confiscada en 1568, junto con otras del pintor, a uno de sus herederos, Guillermo el Taciturno, durante la Guerra de Flandes, sostenida contra las fuerzas españolas. Con el tiempo pasaría a engrosar la rica colección atesorada por Felipe II en El Escorial. ${ }^{3}$

Aunque, como su nombre lo indica, el interés central de un tríptico reside en los tres lienzos que se pueden admirar una vez los paneles o "postigos" laterales abiertos, en realidad la obra consta de cuatro partes si tomamos en cuenta que las "puertas" del tríptico están por lo común decoradas en ambas caras. La obra de El Bosco despliega, pues, ante nuestros ojos admirados, cuatro momentos de un mismo suceso: el devenir de la humanidad. Dos de ellos bascularían hacia lo mitológico, uno se inscribiría en la temática histórica y el cuarto bien podría considerarse de corte profético.

\footnotetext{
${ }^{2}$ Esbocé algunas de las consideraciones siguientes en un comentario a tres obras de Jan publicado en 1992, con el título de "Un nuevo tríptico flamenco. Jan de Vos y la Selva Lacandona “, en Cultura Sur 18: 4-8, CNCA, México. Retomo de él algunas imágenes e ideas y ciertos párrafos.

${ }^{3}$ El tríptico se lo apropió el duque de Alba, al mando de las fuerzas españolas, quien lo heredó a su hijo Fernando. Fue en la almoneda de los bienes de éste donde lo adquirió el rey Felipe. La obra ingresó al Escorial en julio de 1593 («Bosco», Los grandes genios del arte, núm. 25, Eileen Romano (dir.), Unidad Editorial, S.A., 2005).
} 
En las caras exteriores de las puertas del tríptico - por cierto poco conocidas-, El Bosco —empleando la técnica del grisaille— plasmó en tonos verde-grisáceos su muy peculiar idea de lo ocurrido el tercer día de la creación: sobre un fondo negro, un gigantesco globo, transparente en su mitad superior, representa a un mundo cubierto de agua, de la cual se ven surgir plantas y árboles mientas que en el firmamento se separan las luces de las sombras.

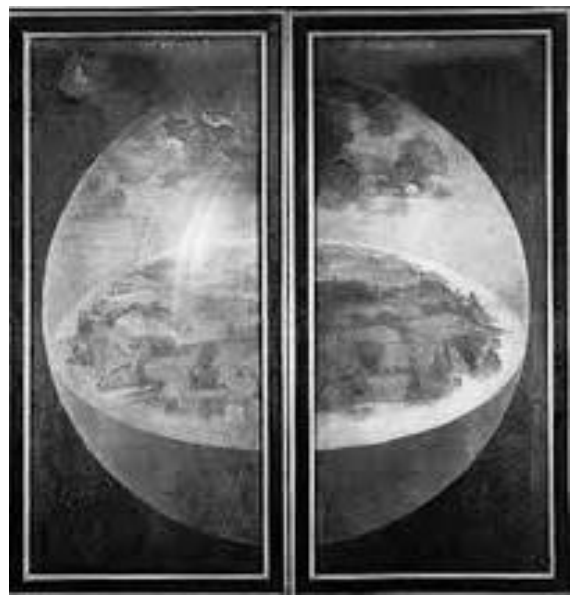

El pintor, aludiendo a la figura divina que aparece en un extremo, escribió en el tablero dos versículos del Salmo 32: "Habló y fue hecho; ordenó y fue creado". De haberlo conocido quizá hubiese empleado aquel poético párrafo del Popol Vuh: "Esta es la relación de cómo todo estaba en suspenso, todo en calma, en silencio; todo inmóvil, callado, y vacía la extensión del cielo... Sólo estaban el mar en calma y el cielo en toda su extensión". 

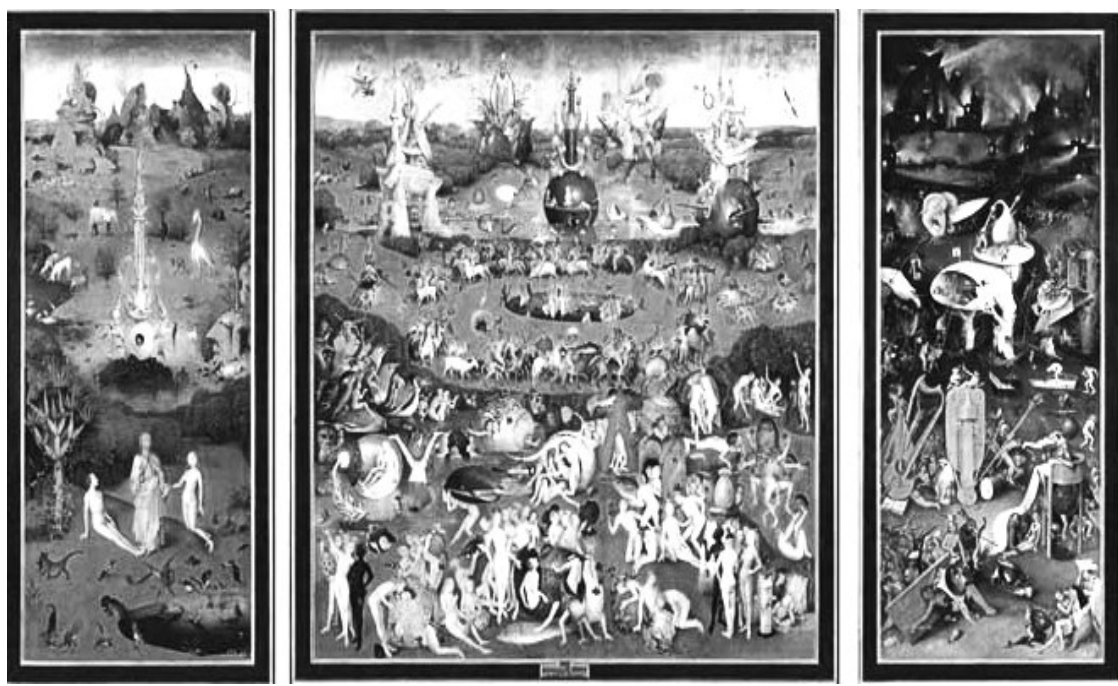

El interior del tríptico es indudablemente más conocido: la escena del primer postigo, retomando la anterior, nos muestra a Dios Padre en el último momento de la Creación: la de Eva, cuya figura se ve equilibrada con un Adán yacente que la mira entre libidinoso y complacido. Al fondo y en torno, escenas de un idílico paraíso animal y arbóreo, ligado a la fuente de la vida, centro de la composición. Atrás, el árbol del conocimiento, en cuyo tronco se enrosca una serpiente. Encima y al pie, animales que en la iconografía de la época encarnaban elementos masculinos — aire y fuego- y femeninos — tierra y agua-, prefigurando, a decir de algunos estudiosos, las escenas que ocuparán la atención del pintor en el siguiente panel; señales ajenas a la paz paradisíaca que suelen interpretarse, por tanto, como aviso de pecado. 


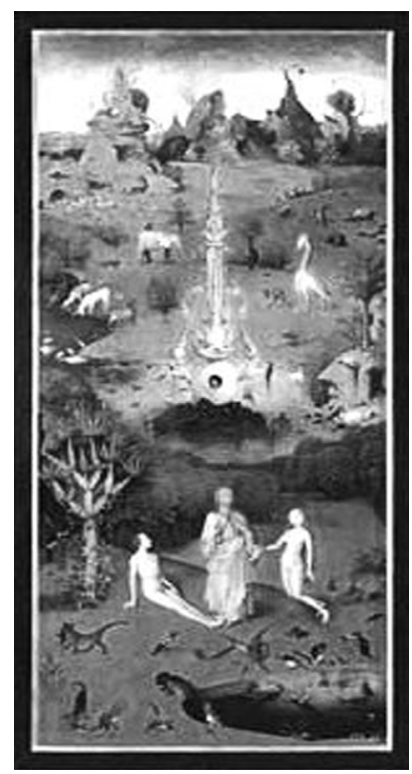

En la porción central de la obra, que dio título al cuadro, además de los cuatro ríos tradicionalmente vinculados con el Paraíso, se aprecia un pequeño estanque en el que se baña un grupo de desnudas bellezas mientras que a su alrededor se desarrolla una lúbrica cabalgata de hombres igualmente desnudos, montados en extraños animales, símbolos de lujuria y gozo terrenal. En la parte inferior, entremezclada con toda suerte de estructuras minerales, plantas y ciertos animales por lo común vinculados en la Edad Media con los placeres de la carne, fulgura una constelación de desnudos en actitudes pecaminosas o alegorías de ellas — como comer frutas, metáfora de la lascivia-. Las costras, pompas y conchas que envuelven u oprimen a varios personajes aluden, en opinión de ciertos críticos, a la prisión que a la postre significa el pecado para el hombre.

El último panel está dedicado a una infernal escena apocalíptica: mientras en el fondo arden las ciudades y agoniza la naturaleza envuelta en ríos de fuego, en el centro Satán, el devorador, da cuenta de los pecadores. Alrededor suyo se despliegan diversos tormentos destinados a castigar a los transgresores de los siete pecados capitales. Así, el mensaje didáctico completa su ciclo: la vida que emergió de las aguas es 
consumida en el fuego; lo que ayer constituyó un placentero comienzo terminará mañana en un macabro holocausto. Desde el legendario pasado idílico hasta el apocalíptico futuro de destrucción.

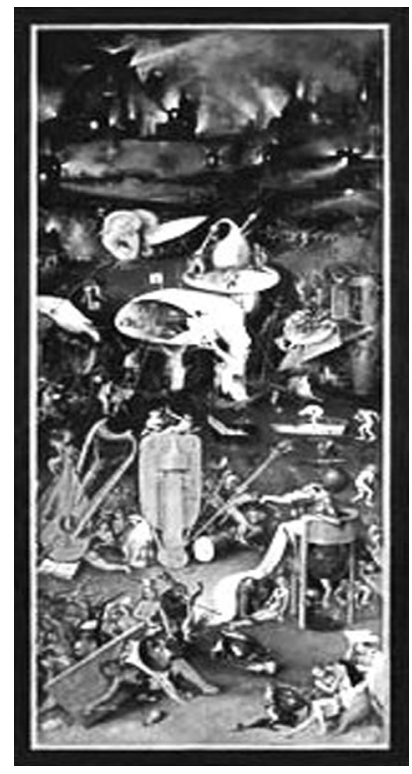

Flamenco de origen, Jan de Vos parece haber recurrido, ignoro qué tan conscientemente, a la técnica del tríptico para dar cuenta de la vivencia histórica del mundo de la Lacandona; no por más local menos humano. En efecto, en los principales libros que publicó sobre la tierra lacandona y sus hombres, vemos plasmado el auténtico Jardín de las delicias que conocieron sus primeros habitantes - que al tiempo que le dieron nombre, Lacam Tun, fueron por él nombrados- y la forma en que el Paraíso terminó siendo subvertido por la conquista hispana ( $\mathrm{La}$ paz de Dios y del rey, 1980), la explotación forestal (Oro verde, 1988) y la infernal devastación en que terminó traduciéndose una colonización feroz y desarticulada consentida, cuando no alentada, por sucesivos gobiernos federales y estatales (Una tierra para sembrar sueños, 2002). 
En tales obras de Vos nos hace transitar del pasado mítico hasta el histórico ayer inmediato, sin ahorrarnos siquiera la nota futurista al aludir a lo que se cierne sobre la selva: un desolado mańana, en el que el antiguo nombre de Desierto de la Soledad estará más que plenamente justificado. Aniquilados sus habitantes originales, malbaratados y desperdiciados sus recursos naturales, la Lacandona no tendrá más destino que el de cualquier otro erial.

Quienes hemos trabajado en la selva durante los últimos años sabemos que su alarma — como la de tantos otros- era más que justificada, pero a diferencia de la de El Bosco, su compatriota, la pintura que de Vos deja entrever sobre el futuro de la selva tiene poco de profético y mucho de constatatorio; la selva es cada día menos selva y cada vez más mera remembranza.

Varios son los momentos en que en la obra de Jan se esboza, con pinceladas a veces magistrales, lo que fue la selva en el pasado: está presente en la visión de fray Pedro de la Concepción —abril de 1695-, en el espléndido relato de Edwin Rockstroh; en las selvas pequeñas que forman la gran selva —ese lugar donde "no hay aquí ni allá, ni principio ni fin, ni arriba ni abajo" - de Jan Litte (Viajes al Desierto de la Soledad, 1980), e incluso en las cifras millonarias de lo reportado por las ventas de la caoba, "el árbol maderable más valioso de América"; ese que Felipe II mandó emplear en puertas, ventanas, estantes y escritorios de El Escorial, y que cubre en cenefas y arabescos de indudable belleza el techo de la basílica de Santa María La Maggiore, en Roma. Ese mismo, paradoja, con que algunos construyen letrinas en los asentamientos selváticos.

Pero la parte de la obra de Vos que corresponde al paraíso de El Bosco no se limita a los elementos naturales; junto a los ríos y lagunas que hacen las veces de fuentes de la vida; junto a las alimañas y serpientes, bastantes más reales que las del Génesis; junto a la caoba, árbol de las tentaciones, aparecen, ocupando de nuevo el centro del paisaje, los habitantes de ese paraíso para siempre perdido. Adán-Xulamná o Mixquitahau y Eva-Izquinchin o Ixmasatuhnol se hacen tangibles en el relato, donde pasan de actores del pasado legendario a víctimas del devenir histórico. Expulsados también del paraíso, los progenitores choltís lacandones acabarán sus días ya no cultivando la tierra con 
su sudor o pariendo sus hijos con dolor —eso lo habían hecho desde siempre - sino que, "ya mansos y conquistados", terminarían por desaparecer de los registros históricos, desterrados a Aquespala, San Román y Santa Catarina Retalhuleu.

La mitología lacandona, sin embargo, transcendió en el tiempo a sus actores, llegando incluso hasta nuestros días. En tal aspecto, el Jan de Vos historiador se impuso al Jan de Vos recreador literario del mito. Así, en el capítulo X de La paz de Dios y del Rey, y en la introducción a sus Viajes al Desierto de la Soledad, el autor nos habla del origen yucateco de los lacandones actuales y de la ignorancia histórica - muy conveniente - de las autoridades, que en 1972 alegaron la permanencia continua en el área — “desde tiempos inmemoriales" de sus descendientes — por entonces menos de 600 personas-, para dotarlos con 614,321 hectáreas, provocando agudos conflictos con otros colonizadores.

Cuando los choltís lacandones, los pobladores originales, fueron expulsados del Edén — bastante mitificado, como todos los edenes-, inició para los nuevos usufructuarios de la selva, los colonizadores hispanos, la posibilidad de disfrutar del jardín de las delicias; una posibilidad de la que, por cierto, bien poco provecho obtuvieron las autoridades y los comerciantes de la época colonial, si exceptuamos las eventuales y no excesivamente productivas explotaciones de bálsamo, zarzaparrilla, achiote o cacao, que se situaron más bien en el área del Petén.

El verdadero disfrute, el de la riqueza arbórea de la selva, tendría que esperar por los tabasqueños y el siglo XIX para alcanzar su vértice hacia 1895 y venir a cerrarse apenas en 1949 . De esa historia, de la cual tampoco están ausentes los mitos —incluido el de hacer responsables a los primeros madereros de la tala más agresiva-, trata Oro verde, un texto que si bien resulta de lectura bastante más densa que La paz de Dios y del rey por la enorme cantidad de cifras que en él se manejan, es complemento indispensable del anterior. La apertura de la Lacandona al gran capital es esbozada con minucia en ese libro, en el cual desfilan desde los primeros ensueños comerciales y falacias geográficas del colecto Cayetano Ramón Robles — sin olvidar las tentativas del fraile dominico Pedro Artica, en 1775, por encontrar una salida al mar 
para los productos de las haciendas que su Orden tenía en la zona de Ocosingo_- hasta la brutal tala llevada a cabo por la empresa Aserraderos Bonampak de 1964 a 1974.

Una vez abierta la selva, conquistados los ríos y zanjada la cuestión de límites con Guatemala, se inició el festín para los iniciados, como lo muestran los contratos de compraventa y deslinde de que da cuenta Jan. Las ganancias fabulosas que generó ese jardín de las delicias se resumen acertadamente en la frase de Louis Martín, cónsul de Francia, quien calificó en 1899 a la explosión forestal lacandona como "el mejor negocio del mundo".

Españoles, franceses y norteamericanos, se sumaron con júbilo capitalista al coro tabasqueño: la selva daba para todos; incluso para las autoridades fiscales. Tan sólo en 1898 la aduana de Frontera, Tabasco, recibió 237,115 pesos por derechos de importación, exportación y uso de puerto. Seis años más tarde los 5,000,000 de pesos en mercancía despachados en este puerto le producirían al Fisco casi 400,000 pesos. Y eso que el de Frontera no era el privilegiado entre los puertos de embarque de madera. Sumando los totales anuales que proporciona de Vos para 1892-1910, tenemos que en esos 18 ańos se recibieron tan sólo en Nueva York 134,454 toneladas de caoba mexicana. Y junto a las cantidades de caoba exportada y sus ganancias, fantásticas para la época, aparecen las de palo de tinte y las de hule, también de importancia.

A diferencia de lo ocurrido en La paz de Dios y del rey, los individuos hacedores de la historia se le pierden a de Vos en Oro Verde, ahogados en un mar de hectáreas, pesos y toneladas, lo que a mi juicio constituye uno de los tropiezos más serios en la factura de este libro. Sin embargo, tal pérdida era de temerse en alguna medida pues la protagonista del texto ya no es más la legendaria y difamada "tribu" choltí lacandona, sino la codiciada caoba. Los hombres cedieron su lugar a la floresta; las puertas del tríptico se cerraron de nuevo para transportarnos otra vez a ese fantástico tercer día de la creación, cuando los árboles surgieron de las aguas, tal como los trozos de caoba de la Lacandona emergían de los ríos a las barras tabasqueñas de Santa Ana, Chiltepec, Dos Bocas y Tupilco; esas mismas por donde hoy fluye el petróleo, envenenando las costas. 
El elemento humano que forjó la riqueza de los otros se muestra, más que en Oro verde, en Viajes al Desierto de La Soledad; compendio de testimonios documentales que lo complementa magistralmente y nos hace aprehender en su totalidad el drama arbóreo y el humano; acaso más literarios en los relatos de Traven, los de Little o Montañez y más científico en los de Charnay, Soustelle y Tambourell, pero igualmente aleccionador en todos ellos, sean sus autores topógrafos, monteros, arqueólogos, etnólogos o misioneros.

El drama final, que tejía su urdimbre en todos los relatos anteriores, se muestra con desenfado en un último libro, al que tituló Una tierra para sembrar sueños. Historia reciente de la Selva Lacandona (19502000), en el que, apelando a imágenes oníricas, da cuenta de la irracional destrucción que en medio siglo han llevado a cabo madereros, campesinos y ganaderos. Se detiene en los continuos y crecientes flujos humanos que explican el crecimiento exponencial de los habitantes de la selva — más de 250,000 hacia el año 2010—; nuevos colonos originarios casi siempre de otros poblados chiapanecos, que se vieron obligados a dejar dada su lacerante pobreza. Procedentes de ecosistemas muy diversos, e ignorantes por lo general del manejo del medio selvático, más pronto que tarde, "se dieron cuenta de que bastan unos pocos ańos para aprender a servirse de la selva, pero que se necesitan siglos para aprender a convivir con ella", como asentaría en su último texto dedicado a la Lacandona, ${ }^{4}$ donde apunta cómo se han iniciado nuevas migraciones, en números cada vez mayores, a las ciudades cercanas, al centro del país o incluso a Estados Unidos. Un nuevo flujo migratorio en marcha, en busca de otras tierras donde continuar sembrando sueños.

De la detallada descripción que de Vos ofrece sobre el fenómeno, en particular en el capítulo III de su libro, se desprende claro cómo se vincula la problemática con los decretos desarticulados, cuando no erráticos, emitidos tanto por los gobiernos estatales como por los federales, para pretendidamente normar el manejo del área. Muestra inicial de ello serían el decreto de 1972, que "inventó" la Zona Lacandona, adjudicándole más de 600,000 hectáreas, al que le seguiría

\footnotetext{
4 "Donde abunda(ba)n los monos sagrados o cómo se fue perdiendo en la Lacandona el arte de convivir con la selva”, Camino del Mayab... (2010: 210).
} 
apenas seis años después el de creación de la Reserva Integral de la Biosfera Montes Azules, con 331,200 hectáreas, montadas en buena medida sobre las primeras. Titubeos, imprecisiones y errores que terminaron por favorecer una política anárquica de colonización —si es que de política alguna puede hablarse- que da clara cuenta de la incapacidad para diseñar programas que concilien de manera armónica el desarrollo sustentable de la selva y de sus moradores.

Hoy, la región es escenario cotidiano de desalojos, reubicaciones —voluntarias unas, otras no tanto-, indemnizaciones en efectivo y "compensaciones" territoriales; luchas partidistas; conflictos entre asentamientos "regulares" e "irregulares", o entre católicos y conversos a ideologías de corte protestante, que pululan como hongos en los asentamientos selváticos. Luchas que dividen a sus pobladores y sustituyen antiguas alianzas comunales por un individualismo radical. Es, a la vez, albergue de contingentes armados tanto insurgentes como contrainsurgentes, vía para el tráfico de drogas e indocumentados, y laboratorio de numerosos proyectos — millonarios algunos- que una y otra vez parecen destinados al fracaso.

Del millón y medio de hectáreas de bosque original, apenas sobrevive una tercera parte. En las cenizas de las otras dos yacen sepultados muchos de los sueños que el historiador invoca en su texto. Un mismo humus sirvió para nutrir las expectativas de algunos que, tras años de esfuerzos por organizarse y dar la batalla, lograron, en cierta medida, convertir algunos de sus anhelos en realidades, mientras que en otros casos funcionó para incubar auténticas pesadillas, como fue el caso de no pocos de aquellos sueños de naturaleza conservacionista.

Si hemos de atenernos al símil elegido, el último panel de la obra pictórica-legendaria e histórico-literaria del flamenco de Vos se correspondería con la dantesca escena de destrucción plasmada por El Bosco en el postigo derecho de su obra: la Lacandona terminará siendo consumida por el fuego, las vacas, el café, la codicia de las empresas madereras, la insensatez humana y la incapacidad de las autoridades para proteger ciertas áreas de la selva a la vez que alentar la explotación racional de otras, atendiendo a su vocación eminentemente silvícola, a la cual sin duda pueden agregarse otras posibilidades de desarrollo, 
incluyendo la turística y la científica, sin "someter la biodiversidad del trópico húmedo a la prospección con fines lucrativos". 5

De darse ese proceso de destrucción irreversible, junto con el entorno natural terminarán por desaparecer las formaciones culturales que florecieron a su amparo, aprendiendo a sustentarse de ella a la vez que velaban por su mantenimiento. Hoy, los choltís lacandones han pasado a ser un mero recuerdo en la mente de algunos investigadores, y la singular etnicidad de los lacandones de origen yucateco va corriendo ya igual suerte.

Sea como fuere, tendremos que continuar agradeciendo a Jan de Vos la magistral pintura secuencial que nos ofrece de la historia de la selva y todo lo que de denuncia contiene; habrá que reconocer su rigor metodológico, lo exhaustivo de sus fuentes y la fluidez de su relato. Pero, sobre todo, tendremos que agradecer a la Lacandona todo lo que ha posibilitado con su existencia, y la mejor forma de hacerlo es tomar conciencia del hecho y contribuir a rescatar y proteger lo que aún queda; poner manos a la obra a fin de intentar un remedio lo suficientemente plástico para atender a la vez las urgencias ambientales y las sociales. Aun a riesgo de frustrar el tríptico de Jan de Vos, debemos luchar para que su última escena, la de la destrucción final, no llegue nunca a pintarse completa.

Ésa es tarea que nos compete a todos, y en particular a sus colegas y alumnos. Porque Jan no fue sólo investigador y escritor, impartió clases y dirigió tesis de grado y posgrado, a la vez que nos instruyó a cuantos tuvimos el privilegio de escucharle. No se requiere de un pizarrón para ser maestro. ${ }^{6}$

Amante de la polémica y el debate, en las reuniones con amigos y colegas ponía en juego el antiguo esquema escolástico del lectio, questio y disputatio, y después de comentarnos algún nuevo asunto o documento descubierto, se enzarzaba en discusiones apasionadas, a veces ríspidas, siempre eruditas, sobre la historia local, el dato puntual o los métodos historiográficos y las formas de comunicar los resultados.

\footnotetext{
5 “Donde abunda(ba)n los monos sagrados...", op. cit., p. 215.

${ }^{6}$ Parte de sus afanes docentes fue su preocupación por allanar el camino para quienes viniesen después, publicando catálogos donde compiló una inmensa cantidad de documentos que había podido ubicar en archivos como el General de Centroamérica y el General de Indias.
} 
Señalaba, por ejemplo, lo descorazonador que le resultaba la dificultad de encontrar arqueólogos que se preocupasen por poner sus valiosos hallazgos a disposición de los no especialistas en manera atractiva - Carlos Navarrete es verdadera rara avis_, el inexplicable desinterés de muchos epigrafistas por aproximarse a la historia y la antropología cuando podrían sustentar en ella tantas hipótesis o desecharlas o, tema recurrente, nos reprochaba a los antropólogos el meternos a hacer historia a menudo sin un manejo adecuado de la metodología, pero por lo común concluía en forma conciliadora - en especial cuando tenía enfrente a la aguerrida Dolores Aramoni.

Puesto que se entrenó para el púlpito no es de extrańar que le apasionaran las labores de difusión y divulgación, por lo que aceptaba gustoso las invitaciones para coloquios, congresos y seminarios, donde sistemáticamente brillaba gracias a sus innegables dotes como conferencista, que a últimas fechas comenzó a combinar con su gusto por el canto, acompańando algunas de sus intervenciones con su guitarra.

Micrófono y pluma en mano se presentó, en cambio, en las dilatadas sesiones entre las instancias de Gobierno, la sociedad civil y el Ejército Zapatista de Liberación Nacional, del que fungió como asesor en el proceso de creación y firma de los Acuerdos de San Andrés Larráinzar (1996), doblemente célebres: por su original factura y por no haber sido cumplidos por parte de las instancias gubernamentales.

No sólo los zapatistas le otorgaron merecido reconocimiento. En 1986 obtuvo el Premio Chiapas en Ciencias, en 1992 el Gobierno de Tabasco le concedió el Juchimán de Plata, en 1999 se le otorgó la presea Vito Alessio Robles y en 2005 Chiapas le distinguió de nuevo, esta vez con el Reconocimiento al mérito estatal de Investigación Científica. Particularmente satisfactoria, en tanto que vino del Gobierno belga, fue la condecoración que recibió en 2003 como caballero de la Orden del rey Leopoldo.

Pocos reconocimientos, según me contaba, le produjeron sin embargo un gozo similar al que experimentó cuando en 2001, en un acto multitudinario, se entregaron a representantes de diversas comunidades indígenas ejemplares de su texto Nuestra raíz, traducido al tzotzil, tzeltal, ch'ol y tojolab'al, las cuatro lenguas mayances 
mayoritarias en el amplio abanico lingüístico del estado, y que escribió para los mayas de Chiapas como un acto de retribución, altamente simbólico, de parte de esa memoria histórica que a menudo hemos expropiado a los pueblos originarios en beneficio exclusivo de una historia pretendidamente única y nacional.

\section{料}

$\mathrm{Si}$, como se titula uno de sus libros, De lejos vienen los torrentes, resulta penitencial agradecer a los llanos flamencos el haber propulsado hasta Los Altos y las selvas de Chiapas ese torrente de metodología acuciosa, reflexión erudita, sabiduría propositiva e indudable bonhomía que fue Jan. Único historiador de Flandes que ha sido capaz, hasta donde sé, de poner una pica en territorio chiapaneco. Único de Vos, sin duda, que, tomando en cuenta su amor por Chiapas, su compromiso con la recreación de la historia regional y nacional, y su universalidad, haya merecido ser saludado en alguna ocasión en Chiapas, como: "Jan de Vos, Jan de tú, Jan nuestro”.

Mario Humberto Ruz Centro de Estudios Mayas, IIF Universidad Nacional Autónoma de México 